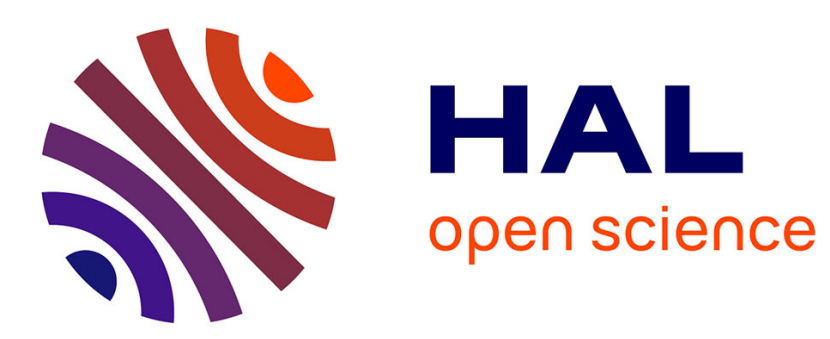

\title{
Clutch size, egg survival and migration distance in the agile frog (Rana dalmatina) in a floodplain
}

\author{
Alain Ponsero, Pierre Joly
}

\section{To cite this version:}

Alain Ponsero, Pierre Joly. Clutch size, egg survival and migration distance in the agile frog (Rana dalmatina) in a floodplain. Archiv fur Hydrobiologie, 1998, 142, pp.343-352. hal-00364739

\section{HAL Id: hal-00364739 \\ https://hal.science/hal-00364739}

Submitted on 20 Jul 2009

HAL is a multi-disciplinary open access archive for the deposit and dissemination of scientific research documents, whether they are published or not. The documents may come from teaching and research institutions in France or abroad, or from public or private research centers.
L'archive ouverte pluridisciplinaire HAL, est destinée au dépôt et à la diffusion de documents scientifiques de niveau recherche, publiés ou non, émanant des établissements d'enseignement et de recherche français ou étrangers, des laboratoires publics ou privés. 


\title{
Clutch size, egg survival and migration distance in the agile frog (Rana dalmatina) in a floodplain
}

\author{
A.Ponsero ${ }^{1} \&$ P.Joly $^{2}$
}

\begin{abstract}
In animals with complex life cycles, the cost of migration among habitats has to be balanced by optimization of growth and survival within each life-stage habitat. In this context, migration distance is expected to depend on local density and movement potential. In ectotherm species, because movement potential is related to body size, larger individuals are expected to cover longer distances than smaller individuals thus avoiding competition. This hypothesis was investigated in the agile frog (Rana dlmatina). For breeding, this species migrates from undergrowth towards ponds located in open environments. Most egg batches were found in sites located $50-100 \mathrm{~m}$ from the forest edge. Batches from larger frogs were more numerous at greater distances, as far as $300 \mathrm{~m}$ from the forest edge thus confirming the hypothesis. These results must be taken into account for the conservation of this endangered species.
\end{abstract}

\section{Introduction}

In animals with complex life cycles, migration from one life habitat to another represents a cost with respect to both energetics and survival. Evolution of complex life cycles supposes this cost to be balanced by optimum fit of each life stage with its particular habitat, a more specialized ecological niche providing better growth and better survival (Istock, 1967 ; Wassersug, 1974, 1975 ; Slade \& Wassersug, 1975 ; Wilbur, 1980). As a consequence, variation in the cost of migration is expected to influence population viability and the evolution of complex cycles. Because the modification of connectivity by human activities can contribute to sudden increase of the cost of migration, this problem of evolutionary biology appears also to be relevant in conservation ecology.

1 Addresse actuelle : Réserve Naturelle Nationale de la Baie de Saint-Brieuc, site de l'étoile, F-2210 Hillion ; alain.ponsero@espaces-naturels.fr

2 Adresse actuelle : Recologie des Eaux Douces et des Grands Fleuves, Université Claude Bernard Lyon I, F-69622 Villeurbanne Cedex ; pjoly@biom-ser.univ-lyon1.fr 
Most holartic anurans show a complex life cycle, with adults migrating from terrestrial towards aquatic habitats where they spawn and where larvae develop. While migrating, these animals have to cross environments which provide neither trophic resource nor high safety against predation. One can expected to be balanced by reproduction success in the site where breeding occurs.

In the holartic zone, such a complex life cycle with migration occurs in numerous species inhabiting forests. In the ponds located within forested areas, dead-leaf accumulation and shade induce hypoxia and low productivity (Williams, 1987). Conditions for tadpole development are then less favourable in these undergrowth aquatic sites than in sites in open environments. In fluvial forests that line the river, the presence of predatory fishes is more likely in undergrowth sites act as selective pressures which determine the species to breed in sites located outside the forested area.

Migration distance may be assumed to result in a trade-off between the cost of crossing non-habitats and the gain provided by the openness of the environment surrounding the breeding site. Because locomotory performances of an individual are generally related to its size (Peters, 1983), the largest individuals are expected to breed in sites that are most distant from the fluvial forest.

Because of the patchy distribution of habitat types, the floodplains of large rivers represent a suitable environment for such a study (Townsend,1989, Petts \& Amoros, 1996). The fluvial forest is inhabited by several anuran species (Joly, 1992). These species can breed either remaining within their terrestrial habitat and spawning in undergrowth ponds, or after migrating towards ponds located outside the forest in the open environment.

In this respect, Rana dalmatina is the most common brown frog inhabiting the alluvial forest of the Mid-Rhône floodplain (Joly \& Morand, 1994 ; Morand \& Joly, 1995 ; Morand, 1996). Its life cycle corresponds to the aim of this study, which is to test the hypothesis of a relationship between body size and distance of the breeding site from the forest (Wederkinch, 1988). This study took place in the Lavours Marsh which is one of the largest fluvial marshes remaining in Western Europe. In this marsh,the aquatic sites were sampled in order to account for variation in substratum (alluvium or peat) which may act as confounding factor.

\section{Material and method}

\section{$\underline{\text { Study site }}$}

The Lavours Marsh is located $70 \mathrm{Km}$ downstream from Geneva. It occupies a 1200 ha hallow between the Rivers Rhône and Seran just upstream from their confluence. The marsh originated in a post-glacial lake progressively filled with sediment. Water flow from the rivers to the marsh was checked by man-made embankments, mainly erected during the XIXth century. The marsh is now overflowed only in decennial floods. Whereas the floods have formed two side bars, mostly occupied by fluvial forest, the central zone of the mash is filled with peat, where the water table is level with the peat surface. The fluvial forest is characterized by Almus glutinosa, Acer campestre and Fraxinus excelsior. The peat-bog is occupied by Schoenus nigricans, Carex elata, Molinia caerulea and Cladium marscus. Detailed ecological descriptions of the Lavours Marsh are given in Ain \& Pautou (1969), Bravard (1987) and Pautou et al. (1991). 
The ponds studied are located in the western part of the marsh near the Seran river ; this zone is managed as a natural reserve. Based on both substratum and openness of surroundings, the ponds studied belong to three types : alluvium and undergrowth (4 sites), peat and undergrowth (3 sites), peat and open surroundings (5 sites).

\section{Egg number and survival}

During the breeding periode of the first year (1994) of the study, 64 clutches were monitored in 12 ponds including representatives of the three habitat sites. Egg number was estimated by measuring the volume of each batch in a test tube. The relationship between egg number and batch volume was drawn from counting the egg in 30 batches. Eggs were counted by laying down the batch on the square-ruled bottom of a tank. The location of each batch in the pond was noted as one of three modalities : resting on the bottom, hangig under water from a support, or floating. Before hatching, egg survival in each batch was estimated by counting degenarative embryos.

\section{Clutch size, female size and distance of site to the forest}

During the second year (1995), 28 ponds were sampled according to their distance to the forest and were checked for clutches. Area, depth, substrate and distance to forest were measurd. In these sites, $107 \mathrm{egg}$ batches were collected and their volme estimated as previously described. In this study, because egg number is closely related to female body size in ranids (Salthe \& Duellman, 1973 ; Cummins, 1986 ; Joly, 1991), it is used as an indicator of female size.

\section{Results}

The volum (V) of 30 btchesvaried from 200 to $700 \mathrm{ml}$ (mean : $382 \pm 26 \mathrm{ml}$ ). Egg numbers (N) varied from 526 to 2086 eggs. These data fit the linear model $\mathrm{N}=2.35 \mathrm{~V}+127.45\left(\mathrm{r}^{2}=0.81, \mathrm{p}<0.0001\right)$. This model is very close to that found by Waringer-Löschenkohl (1991) in the same species $(\mathrm{N}=2.25 \mathrm{~V}+134.97 ; \mathrm{n}=10)$. It will be used hereafter for estimating egg number.

Clutch size did not vary significantly among the three habitat types (table 1) (ANOVA on clutch volume : $\mathrm{p}=0.10)$, nor did egg number of each clutch vary according to oviposition location (on the bottom : $\mathrm{n}=1007 \pm 107$; hangig $929 \pm 81$; floating : $888 \pm 75$; ANOVA, $\mathrm{p}=0.6$ ).

\begin{tabular}{lccc}
\hline Habitat type & $\begin{array}{l}\text { Number of } \\
\text { clutches }\end{array}$ & $\begin{array}{l}\text { Mean clutch size } \\
(\mathrm{ml})\end{array}$ & $\begin{array}{l}\text { Estimated egg } \\
\text { number }\end{array}$ \\
\hline $\begin{array}{l}\text { Alluvium and } \\
\text { undergrowth }\end{array}$ & 21 & $315.7 \pm 27.8$ & $822.8 \pm 59.1$ \\
$\begin{array}{l}\text { Peat and } \\
\text { undergrowth }\end{array}$ & 15 & $322.0 \pm 18.3$ & $842.4 \pm 57.8$ \\
\begin{tabular}{l} 
Peat and open field \\
\multicolumn{3}{r}{ Table 1. Mean clutch size according to habitat type }
\end{tabular}
\end{tabular}


Egg survival varied significantly among habitat types $\left(\chi^{2}=5673, \mathrm{p}<0.0001\right)$ (table 2$)$. Whereasit reached $100 \%$ in alluvium sites, egg survival varied from $66 \%$ to $100 \%$ in peat sites. In these sites, egg survival was significantly related to laying position with lower survival in batches resting on the bottom $(67.7 \%)$ than in floating batches $(86.1 \%)$ or hanging batches $(88.1 \%)\left(\chi^{2} ; \mathrm{p}<0.0001\right)$.

\begin{tabular}{llcc}
\hline Habitat type & Batch location & N batches & Survival \\
\hline Undergrowth, alluvium & On the bottom & 0 & - \\
& hanging & 3 & 100 \\
& floating & 18 & 100 \\
Undergrowth, peat & On the bottom & 3 & $82.0 \pm 1.3$ \\
& hanging & 6 & $91.7 \pm 3.8$ \\
& floating & 6 & 100 \\
Open surrounding, peat & On the bottom & 16 & $65.6 \pm 9.2$ \\
& hanging & 7 & $85.7 \pm 12.7$ \\
& floating & 5 & $73.0 \pm 13.9$ \\
\hline
\end{tabular}

Table 2. Relationship between survival and both habitat type and oviposition location.

The relationship between clutch size and adult migration distance was studied during the second year. Most of the batches (75\%) were censused in open fields within $100 \mathrm{~m}$ from the forest border. Batch density reached a maximum $\left(1\right.$ batch per $\left.4 \mathrm{~m}^{2}\right)$ in sites located from 50 to $80 \mathrm{~m}$ from the forest and lowest values $\left(1\right.$ batch per $\left.20 \mathrm{~m}^{2}\right)$ for distances exceeding $100 \mathrm{~m}$ (fig.1). 


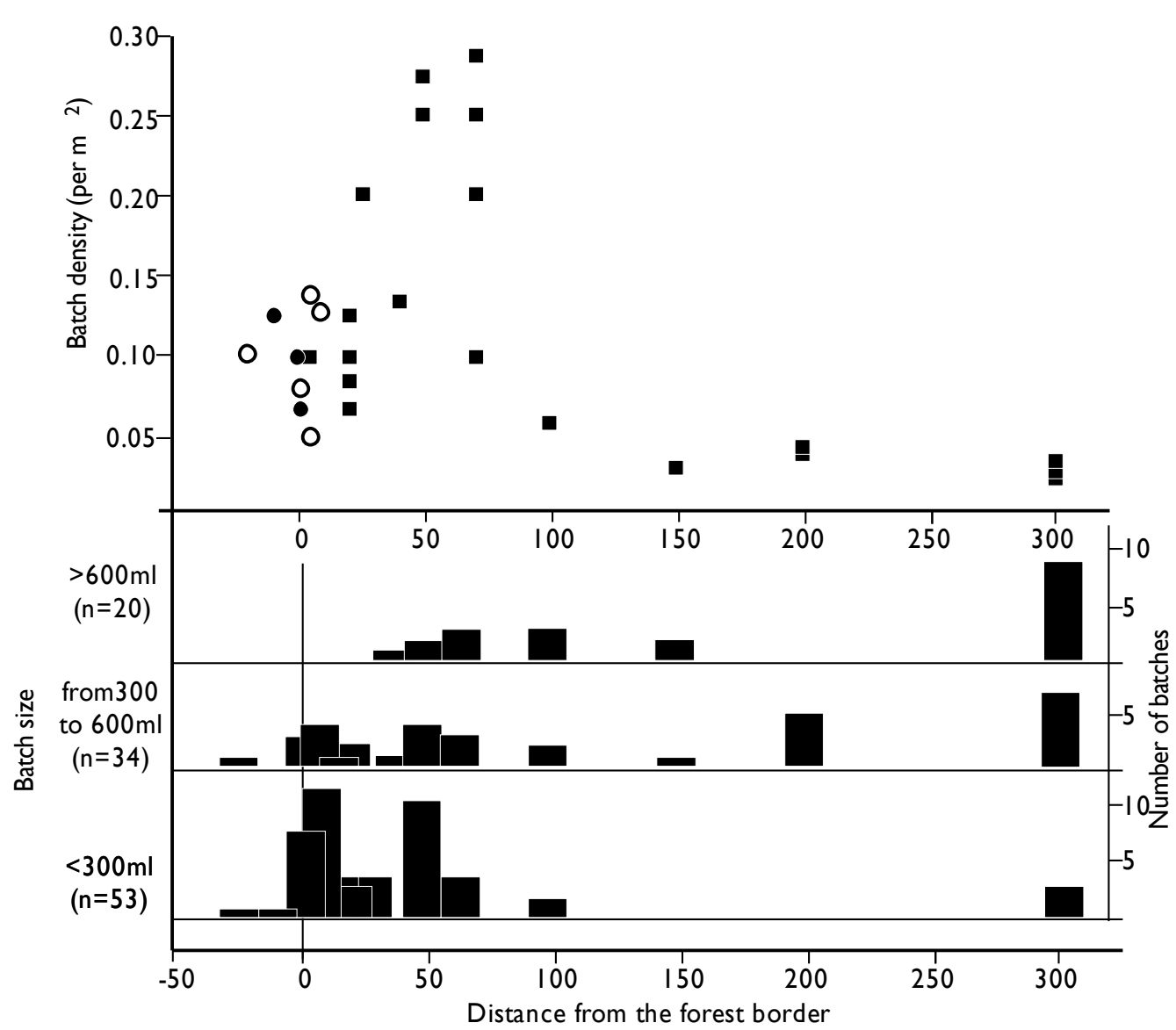

Fig. 1. Top : Relationship between batch density and distance to the forest. Black dots : fishless sites; open dots : sites with fish. Circles : sites in alluvium; squares : sites in peat. Bottom : distribution of batch numbers in relation with both batch size and distance to the forest.

Clutch size was related to distance from the forest. Whereas the smallest batches were mainly recorded in sites within $100 \mathrm{~m}(72.7 \%$ of $>600 \mathrm{ml}$ batches ; $\mathrm{n}=20)$. Batches with inermediate size distributed on both sids of a $100 \mathrm{~m}$ distance from the forest $(59.4 \%$ of batches between 300 and $600 \mathrm{ml}$ in sites within $100 \mathrm{~m}$ distance ; $=34$ ) (fig.1). This variation in batch distribution related to size was highly significant $\left(\chi^{2} ; \mathrm{p}<0.0001\right)$. Because egg number is strongly related to female size in ranids (Salthe \& Duellman, 1973 ; Cummins, 1986 ; Joly, 1991), migrations were longer in larger females than in smaller females (mean distance $=40.8 \pm 9.6 \mathrm{~m}$ for batches $<300 \mathrm{ml}$ ) and led them to the most distant sites from the forest (mean distance $171 \pm 26 \mathrm{~m}$ for batches $>600 \mathrm{ml}$ ). Migration distances were intermediate for medium-size females (mean distance $=115.0 \pm 19.8 \mathrm{~m}$ for batches from 300 to $600 \mathrm{ml})$. 


\section{Discussion}

As expected, most frogs spawned outside the undergrowth. This result confirms the former study of Wederkinch (1988), which showed that in an agricultural zone most eggclutches were laid within a $200 \mathrm{~m}$ distance from the forest. However, in the present study, the distance covered by the larger females was greater than covered by the smaller ones.

Avoiding spawning in the undergrowth presents several advantages. Our results show that the presence of fish in pond is indeed more frequent within the fluvial forest where floods occur more often. Fish are among the most efficient predators of tadpoles (Semlitsch \& Gibbons, 1988). The highest batch densities were recorded in a zone 50-100m from the forest border, just outsite the one where fish occurred. On the other hand, despite the lack of measures of oxygen concentration and algual productivity, we can assume that the accumulation of organic mater (dead leaves, dead wood) together with the shading in undergrowth ponds are causes for less food and less oxygen in thses sites than in the open environment.

However, the relationship between migration distance and frog size cannot be explained only by the probability of fish occurrence and variation in productivity. If we reasonably accept that medium-sized frogs can travel the minimum distance for reaching the suitable sites closest to the forest border, an optimality model would predict that the largest-sized frogs should also spawn in these closest sites (fig.2A). Because this expectation was not validated, the model must be modified by incorporating a negative impact of tadpole density on habitat quality (fig.2B). The negative effect of density on tadpole growth has been demonstrated in numerous studies (Wilbur, 1977 ; Travis, 1984 ; Mahapatro \& Dash, 1987 ; Tejedo \& Reques, 1992) and we can expect that reproductive success of a female is inversely related to density of tadpoles in the spawning site. Tadpole density is expected to reach its highest level in the sites closest to the forest border. This second model shows how such a decrease of medium-sized and large-sized frogs. Tadpole density and migration distance are expected to interact in sharing the decrease in habitat quality as show in Fig.2C, thus separating the optimum migration distances for the three size classes. 

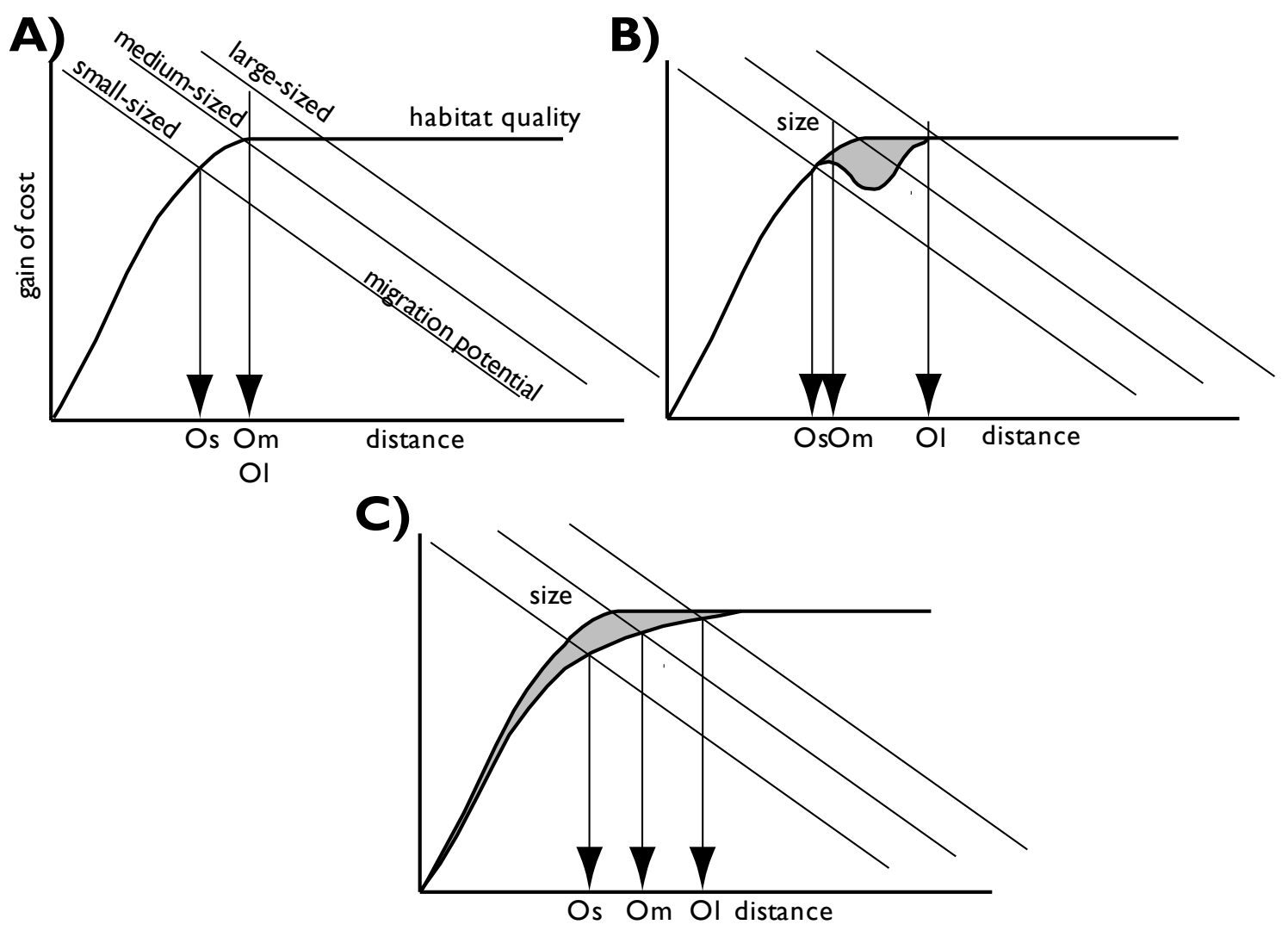

Fig. 2. Graphical optimization models explaining the relationship between migration distance and body size (expressed by clutch size). The model considers that habitat quality, and consequently expected fitness gain, increase with the distance to forest border until a limit beyond which habitat quality remains constant. Before reaching this limit, habitat quality is altered by accumulation of dead leaves, forest shade, and predation by fish. Migration potential represents the energetic investment in movement and mortality risk associated with movement. It is assumed to decrease linearly with the distance covered. The potential is higher in large-sized frogs because of higher movement capacity in largesized animals. The optimum migration distance is the shortest migration distance maximizing the trade of between migration cost and gain in reproduction. In $\mathrm{A}$, the optimum distance is similar in medium-size $\left(\mathrm{O}_{\mathrm{m}}\right)$ and large-sized $\left(\mathrm{O}_{\mathrm{l}}\right)$ frogs. In $\mathrm{B}$, habitat quality is assumed to be altered by high tadpole density at the optimum distance estimated in A. As a consequence, optimum migration distances of medium-sized and large-sized frogs diverge. In $\mathrm{C}$, interactions of tadpole density an migration constraints share the impact of density on the habitat quality curve (shaded area), defining new migration distance optima for each size class $\left(\mathrm{O}_{\mathrm{s}}\right.$ : optimum for the small-size frogs). 
If such graphical models are useful in identifying testable hypotheses, models using evolutionary stable strategy 5ESS) would predict more formally the fitness equilibrum under both constraints of tadpole density and migration distance.

If we expect a better survival and better growth rate of tadpoles in ponds far away from the forest border, a problem remains in the higher cost of the migration of the juveniles towards the forest than in closer sites. No data are available to evaluate such a cost, and we can assume that the benefits from growing in low density sites, such as reaching a greater body size than in high density sites, compensate for migration cost.

In contrast with these expectations, egg survival was lowest in the ponds furthest from the forest. We hypothesize that the peat substratum of these sites explains such mortality, because mortality was highest when the eggs were in contact with the peat. In single batches, only the lower eggs which were in direct contact with peat died. In this context, the spawning behaviour of the agile frogs that hung up their batches on midwater supports (stems, branches) proved to be adaptive. However, within the peat-bog of the Lavours Marsh, the ponds were not sufficiently deep to avoid contact of the batches hung up with the bottom. As a consequence, egg mortality was relatively high in these shallow sites (the mean depth where batches were laid was $25 \mathrm{~cm}$ in the study of Kecskes \& Puky, 1992). This result does not agree with the former conclusion according to which the frogs would benefit from spawning outside the fluvial forest. However, a conclusion to the advantage of migration would require a measure of tadpole growth and survival in the ponds where the frogs spawn. On the other hand, the presence of a large peat marsh in the vicinity of a fluvial forest is not very common in alluvial floodplains. More often ponds are the remnants of former channels and their bottom is made of alluvium rather than of peat.

Another difficulty results in disagreement between the hypothesis of optimization of migration distance and the hypotheses of philopatry or of site fidelity which are commonly accepted. However, philopatry still remains a matter of debate, because this concept has never been validated unequivocally in amphibians. Site fidelity has been experimentally evidenced only in few species (Joly \& Miaud, 1989 ; Sinsch, 1992) and nomadic behaviour has also been demonstrated in other species (Fog, 1993). Site fidelity is expected to occur in iteroparous species in which migration mechanisms can use information gathered from previous reproductive events. In species where most individuals breed only once, such as Rana dalmatina (Guarino et al., 1995), other criteria than previous experience may prevail in migration guidance. On the other hand, despite an indeterminate growth, a positive relationship between age and body size has never been evidenced in frogs of the genus Rana (Gibbons \& McCarthy, 1986 ; Augert, 1992). As a consequence, a larger body size does not suggest a previous experience of breeding migration.

The agile frog has been listed as an endangered species in Appendix II of the Bern Convention. This study contributes to the conservation ecology of this species in demonstrating the necessity of preserving together the fluvial forest and the ponds located within several hundred metres from the forest. Moreover, migration success needs high connectivity between ponds and forest. When ponds are lacking, they can be restored by dredging provided a surficient connectivity with the forest is established. 


\section{Reference}

AÏN G. \& PAUTOU G.(1969): Etude écologique du marais de Lavours (Ain) - Université Grenoble, 7: 25-64

AUGERT D. (1992) : Variations de la structure démographique de populations voisines de grenouilles rousses (Rana temporaria L.) - Thesis University Lyon I, 142p.

BRAVARD J.P. (1987) : Le Rhône, du Léman à Lyon - La Mnufacture, Lyon, 451p.

Cummins C.P. (1986) : Temporal and spatial variation in egg size and fecundity in Rana temporaria - J. Anil. Ecol. 55:303-316

FOG K. (1993): Migration in the tree frog Hyla arborea. - In : STUMPEL, A.H.P. \& TESTER U. (eds.): Ecology and conservation of the European tree Frog. - Proceesings of the $1^{\text {st }}$ International Workshop on Hyla arborea, 13-14 February 1992, Potsdam, Germany, 55-64.

GIBBONS, M.M. \& MCCARTHY T.K. (1986): The reproductive output of frogs Rana temporaria L. with particular reference to body size and age. - J. Zool., Lond. 209:579593.

GUARANO F. M., ANGELINI F. \& CAMMAROTA M. (1995): A skeletochronological analysis of three syntopic amphibian species from Southern Italy. - Amphibia-Reptilia 16: $297-302$

ISTOCK C.A. (1967): The evolution of complex life cycle phenomena: an ecological perspective. - Evolution 21: 592-605.

JOLY P. (1991): Variation in size and fecundity between neighbouring populations in the common frog, Rana temporaria. - Alytes 9:79-88.

JOLY P. \& MIAUD C. (1989): Fidelity to the breeding site in the Alpine newt Triturus alpestris. - Behav. Process. 19: 47-56.

JOLY P. \& MORAND A. (1994): Theoretical habitat templets, species traits, and species richeness: amphibians in the Upper-Rhône floodplain. - Freshwat. Biol. 31: 455-468.

KECSKES F. \& PUKY M. (1992): Spawning preference of the agile frog, Rana dalmatina. In: KORSOS Z. \& KISS I. (eds.)/ Proc.Sixth Ord.Meet. S.E.H., Budapest 1991, 251 254.

MAHAPATRO B.K. \& DASH M.C. (1987): Density effect on growth and metamorphosis of Bufo stomaticus larvae. - Alytes 6:88-98.

MORAND A. (1996): Dynamique de la coexistence des espèces: de la théorie des perturbations à la théorie des traits d'histoire de vie. L'exemple du modèle amphibien dans l'espace alluvial du Haut-Rhône. - Thesis Université Lyon I, 194p.

MORAND A. \& JOLY P. (1995): Habitat variability and space utilization by the amphibian communities of the French Upper-Rhône floodplain.- Hydrobiologia 300/301: 249257.

PAUTOU G., MAJCHRZAK Y., MANNEVILLE O., GRUFFAZ R. \& MOREAU D. (1991): Dynamique de la végétation et gestion de la réserve naturelle du marais de Lavours (Ain). - Rev. Géogr. Lyon 66:61-70.

PETERS R.H. (1983): The ecological implications of body size.- Cambridge University Press, Cambridge, 329p.

PETTS G.E. \& AMOROS C. (1996): Fluvial hydrosystems. Chapman \& Hall, London, 322p.

SALTHE S.N. \& DUELLMAN W.E. (1973): Quantitative constraints associated with reproductive modes in anurans. - In: VIAL J.L. (ed.): Evolutionary biology of the 
anurans: contempory research on major problems. - University Missouri Press, Columbia, 229-249.

SELMLITSCH R.D. \& GIBBONS J.W. (1988): Fish predation in size-structured populations of treefrog tadpoles. - Oecologia 75: 321-326.

SINSCH U. (1992): Sex-biassed site fidelity and orientation behaviour in reproductive natterjack toads (Bufo calamita). - Ethol. Ecol. Evol. 4:15-32.

SLADE N.A. \& WASSERSUG R.J. (1975): On the evolution of complex life cycles.Evolution 29:568-571.

TAJEDA M. \& REQUES R. (1992): Effects of egg size and density on metamorphic traits in tadpoles of the natterjack toad (Bufo calamita). - J. Herpetol. 26:145-152.

TOWNSEND C.R. (1989): The patch dynamics concept of stream community ecology. - J. N. Amer. Benthol. Soc. 8:26-50

TRAVIS J. (1984): Anuran size at metamorphosis: experimental test of a model based on intraspecific competition. - Ecology 62:1155-1160.

WARINGER-LÖSCHENKOL A. (1991): Breeding ecology of Rana dalmatina in Lower Austria: a 7-years study. - Alytes 9:121-134.

WASSERSUG R. (1974): The evolution of anuran life cycles. - Science 185: 377-378.

WEDERKINCH E. (1988): Polulation size, migration barriers and other observations of Rana dalmatina populations near Køge, Zeeland, Denmark. - Memorrando Soc. Fauna. Flora Fen., 64: 101-103.

WILBUR H.M. (1977): Density-dependant aspects of growth and metamorphosis in Bufo americanus. - Ecology 58: 196-200.

WILLIAMS D.D. (1987): The zoology of temporary waters . - Croom Helm Ltd., Bechenham (UK), 205p.

Submitted: 7 November 1997; Accepted : 16 february 1998. 